\title{
SARI KACANG HIJAU SEBAGAI ALTERNATIF MENINGKATKAN PRODUKSI AIR SUSU IBU (ASI) PADA IBU MENYUSUI
}

\section{NIKMAH JALILAH RITONGA ${ }^{1}$, EKA DEFI MULYANI ${ }^{2}$, DIAH EVAWANNA ANUHGERA1, DAMAYANTI ${ }^{4}$, RIRIS SITORUS $^{5}$, WILDA WAHYUNI SIREGAR ${ }^{6}$}

\author{
1,2,3,4,5,6 INSTITUT KESEHATAN MEDISTRA LUBUK PAKAM \\ Jl. Sudirman No.38 Lubuk Pakam Kab. Deli Serdang \\ Email : ritonganikmah@yahoo.com
}

DOI : https://doi.org/10.35451/jkf.v2i1.272

\begin{abstract}
Nursing mothers belong to one of the vulnerable groups of nutrition, because breast milk which is the main food for babies is obtained from the mother. Therefore, mothers who are breastfeeding must be controled to the intake of nutrients consumed. green beans as a food source of vegetable protein which has been very popular in everyday life. Based on the amount every 100 grams, protein is the second main constituent after calories, which contains $22.2 \%$ protein. The purpose of this study was to determine the effect of consumption of mungbean juice on breast milk production in nursing mothers. This research is a quantitative study with a pre-experimental design with one group pretest posttest, with a population of 20 breastfeeding mothers (0-2 months) and a total sample of 11 nursing mothers who delivered at Klinik Pratama Tutun Sehati. Data collection uses an observation sheet using indicators of Smooth Milk Production. The characteristic equality test showed that there was an effect of consuming mung bean extract on breast milk production in nursing mothers ( $p>a, a \leq 0.05)$. The results of the analysis test with the Wilcoxon test showed that there was a smooth effect of breast milk production $(p=0.046)$. It was recommended for nursing mothers whose milk was not smooth to pay attention to nutritional intake in order to improve the quality and amount of milk production, in packaging because the price is also affordable.
\end{abstract}

Keywords: Green Beans, Breast Milk Production, Breastfeeding Mothers.

\section{Pendahuluan}

Angka Kelahiran Hidup di Indonesia pada tahun 2017 sebanyak 4.840.511 menurun dibandingkan tahun 2016 sebanyak 4.867.813 (Pusdatin, 2018). Pemberian ASI di Indonesia sampai 6 bulan 35,73 \% sedangkan persentase bayi yang menyusu ASI ekslusif sampai 6 bulan di Sumatra Utara saat ini masih memprihatinkan 10,73 \% menempati urutan terendah (Pusdatin, 2018).
Minimnya kesadaran masyarakat dalam meningkatkan pemberian ASI eksklusif, padahal pemberian ASI ekslusif mengurangi tingkat kematian bayi yang disebabkan berbagai penyakit menimpa anak-anak salah satunya diare dan radang paru, selain itu juga membantu mempercepat pemulihan bila bayi sakit dan membantu pasangan usia subur dalam menjarakkan kehamilan (Maryunani.A, 2018). 
Received: 26 September 2019 :: Accepted: 15 Oktober 2019:: Published: 31 Oktober 2019

\section{Asi Ekslusif merupakan} pemberian ASI saja pada bayi usia 0-6 bulan tanpa memberikan makanan tambahan cairan lain seperti susu formula, jeruk, madu dan air teh. selain itu makanan tambahan juga tidak dianjurkan baik dalam bentuk padat maupun cair. Setelah berusia 6 bulan, bayi mulai diberikan makanan tambahan atau makanan pendamping ASI (MPASI). Pemberian ASI dapat diberikan sampai bayi berusia 2 tahun. Pedoman internasional merekomendasikan ASI ekslusif berdasarkan bukti ilmiah terkait manfaat ASI (Maryunani,2018).

Beberapa penelitian menjelaskan bahwa komposisi ASI saja sudah cukup untuk pertumbuhan dan perkembangan bayi usia 0-6 bulan apabila diberikan secara tepat dan benar. Namun nyatanya, $60 \%$ bayi berusia 4 bulan sudah diberikan tambahan susu formula. Beberapa penelitian menjelaskan bahwa komposisi ASI saja sudah cukup untuk pertumbuhan dan perkembangan bayi usia 0-6 bulan apabila diberikan secara tepat dan benar. Namun nyatanya, 60\% bayi berusia 4 bulan sudah diberikan tambahan susu formula. Bayi rentan mengalami alergi karena jaringan usus halus bayi seperti saringan pasir, poriporinya berongga sehingga protein ataupun kuman dapat langsung masuk ke sistem peredaran darah. Bayi berusia 6 bulan sistem pencernaannya mulai matur. Pori-pori usus bayi akan tertutup rapat setelah berusia 6 bulan, sehingga faktor alergi ataupun kuman yang masuk ke dalam darah dapat ditolak (Ambarwati, 2018).

Sebagaimana penelitian WHO pernah menyampaikan bahwa alasan terbanyak ibu menghentikan pemberian ASI ekslusif karena merasa ASI-nya tidak mencukupi kebutuhan bayi. Sekitar $35 \%$ ibu menghentikan pemberian ASI secara ekslusif pada beberapa minggu postpartum karena merasa ASI kurang dan bayi merasa tidak puas (Sutanto.A,
2018). Hasil penelitian (Fikawati dkk, 2012) Prevalensi Persepsi ASI Kurang pada 3 studi yang dikaji terlihat tinggi diatas $30 \%$, masing-masing di Kabupaten Karawang (41,4\%), Kecamatan Tanjung Priok (32,0 \%), dan Kecamatan Cilandak (37\%). Ibu menyusui harus mendapatkan tambahan protein 20 gram setiap hari, karena dalam 100 cc ASI terdiri dari 1,2 gram protein. Selain membentuk protein dalam ASI, kebutuhan protein juga dibutuhkan untuk sintesis hormone produksi ASI (Prolaktin) dan hormon sekresi ASI (Oksitosin). Sumber protein ini dapat diperoleh dari ikan, daging ayam, daging sapi, telur, telur, susu, dan juga tahu, tempe, sera kacangkacangan. Jika kebutuhan protein tidak terpenuhi dari makanan maka protein diambil dari protein ibu yang berada di otot. Hal ini mengakibatkan ibu menjadi kurus dan setelah menyusui akan merasa lapar (Sulistyoningsih H, 2017).

Ibu Menyusui merupakan salah satu gologan yang termasuk kedalam kelompok rentan gizi. Hal ini sesuai dengan amanah UU Kesehatan No. 36 Tahun 2009 Bab III pasal 142. Ibu menyusui tergolong ke dalam salah satu kelompok rentan, sebab ASI yang merupakan utama bayi diperoleh dari ibu. Oleh sebab itu, ibu yang sedang menyusui harus memperhatikan asupan zat gizi yang dikonsumsi. Sekresi dari ASI setiap hari rata-rata $800-850 \mathrm{ml}$ dan setiap $100 \mathrm{ml}$ mengandung $60-65 \mathrm{KKal}$, protein 1-1,2 g, dan lemak 2,5-3,5 g setiap $100 \mathrm{ml}$. Zat-zat dalam sekresi ASI diambil dari tubuh ibu menyusui yang didapatkan suplai makanan sehari-hari. (Maryunani. A, 2018)

. Ibu yang tidak mampu menggantikan zat gizi yang diberikan kepada bayi, beresiko mengalami gizi kurang atau bahkan masalah kesehatan, seperti osteoporosis, kerusakan gigi, dan kekurangan energy kronis (KEK). Masalah pada ibu menyususi yang disebabkan oleh kekurangan gizi: anemia zat besi,Gangguan Akibat 
Kekurangan Yodium (GAKI), Kurang Energi Protein (KEP), dan kekurangan vitamin D (Winarsih, 2018).

Kandungan gizi kacang hijau cukup tinggi dan komposisinya lengkap. Berdasarkan jumlahnya, protein merupakan penyusun utama kedua setelah karbohidrat. Kacang hijau mengandung 20-25 \% protein. Protein tinggi sangat diperlukan oleh ibu selama laktasi, terutama proteinnya mengandung asam amino sehingga mampu merangsang sakresi ASI. Kacang hijau juga mengandung senyawa aktif yaitu polifenol dan flavonoid yang berfungsi meningkatkan hormone prolaktin. Ketika hormone prolaktin meningkat maka sekresi susu akan maksimal sehingga kuantitas ASI akan meningkat dan kandungan gizi yang terdapat dalam sari kacang hijau akan meningkatkan kandungan gizi dalam ASI. (Suskesty, 2017)

Hasil penelitian WidyaAstuti tahun 2014 didapatkan bahwa Mengkonsumsi Sari Kacang Hijau berpengaruh Terhadap Produksi Air Susu Ibu (ASI) pada Ibu Menyusui di Puskesmas Dinoyo Malang. Penelitian Wulandari tahun 2015 juga menjelaskan bahwa Pemberian Sari Kacang Hijau pada 7 orang ibu menyusui terdapat 4 orang $(57,1 \%)$ yang ASInya keluar dengan lancar dan 3 orang $(42,9 \%)$ yang ASInya tidak lancar. kesimpulannya semakin sering mengkonsumsi sari kacang hijau pengeluaran ASI semakin lancar.

Dari hasil survei awal di lokasi penelitian pada tanggal 28 April 2019 di dapat 6 ibu menyusui, dari 6 ibu menyusui tersebut 2 ibu mengatakan ASI nya keluar dengan dengan lancar dan 4 diantaranya ASI Tidak lancar dengan 2 diantaranya menggunakan susu formula sebagai tambahan karena ASI Tidak mencukupi kebutuhan bayi.

\section{METODE}

Penelitian ini menggunakan desain pra eksperimen, dengan One Group Pretest posttest, tanpa menggunakan kelompok pembanding (Kontrol), namun dilakukan observasi pertama (pretest) untuk menguji perubahan-perubahan yang mungkin terjadi setelah ekperimen (Program). Produksi ASI diukur pada saat sebelum dan sesudah pemberian Sari kacang hijau. Populasi dalam penelitian ini adalah ibu menyusui (0-2 bulan) yang bersalin di Klinik Pratama Tutun Sehati. Sampel yang memenuhi kriteria inklusi penelitian yaitu ibu menyusui yang bersalin di klinik pratama Tutun Sehati yang bersedia menjadi responden dan yang mengalami masalah dalam produksi ASI akan dimasukkan kedalam penelitian dengan menggunakan teknik Purposive Samplingi sampai jumlah sampel terpenuhi yaitu 11 orang.

Sari kacang hijau yang diberikan kepada sampel penelitian adalah minuman sari kacang hijau merek Ultra Jaya $250 \mathrm{ml}$ yang beredar di pasaran. Alasan peneliti menggunakan minuman yang sudah beredar di pasaran karena jika menggunakan sari kacang hijau yang di buat sendiri oleh peneliti, belum melewati standard uji coba dosis serta kehigienisan.

Sebelum diberikan sari kacang hijau responden diobservasi produksi ASI-nya terlebih dahulu selama 1 minggu kemudian diberikan sari kacang hijau sebanyak $250 \mathrm{ml}$ per hari selama 6 hari, kemudian diobservasi kembali produksi ASI Ibu Menyususi apakah Lancar atau Tidak. Penelitian ini menggunakan lembar observasi yang berisi indikator kelancaran ASI yang terdiri dari frekuensi BAK dan dan warna urine, frekuensi $B A B$, warna dan konsistensi fases, jumlah jam tidur, serta Berat Badan Bayi. ASI dikatakan lancar jika hasil penilaian minimal 4 dari 6 indikator yang diobservasi terdapat pada bayi $(\geq 4)$. Sedangkan jika kurang dari $4(<4)$ dikatakan tidak lancar.

\section{HASIL}

Tabel 1. Distribusi Karakteristik Responden di Klinik Pratama Tutun Sehati Tahun 2019

\begin{tabular}{|c|c|c|c|c|}
\hline No & Variabel & Kategori & Frekuensi & $\%$ \\
\hline \multirow[t]{5}{*}{1.} & Umur & $20-25$ & 7 & 63,6 \\
\hline & & $26-30$ & 3 & 27,3 \\
\hline & & $31-35$ & 0 & 0 \\
\hline & & $35-40$ & 1 & 9,1 \\
\hline & Jumlah & & 11 & 100 \\
\hline 2. & Pendidikan & $\begin{array}{l}\text { SMA atau } \\
\text { Sederajat }\end{array}$ & 8 & 72,7 \\
\hline
\end{tabular}


Received: 26 September 2019 :: Accepted: 15 Oktober 2019:: Published: 31 Oktober 2019

\begin{tabular}{|c|c|c|c|c|}
\hline & & D1 & 1 & 9,1 \\
\hline & & S1 & 2 & 18,2 \\
\hline \multicolumn{2}{|r|}{ Jumlah } & & 11 & 100 \\
\hline \multirow[t]{5}{*}{3.} & Pekerjaan & IRT & 6 & 54,6 \\
\hline & & Guru & 1 & 9,1 \\
\hline & & Buruh & 2 & 18,2 \\
\hline & & Karyawan & 1 & 9,1 \\
\hline & Jumlah & & 11 & 100 \\
\hline \multirow[t]{3}{*}{4.} & Parietas & Primipara & 7 & 63,6 \\
\hline & & Multipara & 4 & 36,4 \\
\hline & Jumlah & & 11 & 100 \\
\hline
\end{tabular}

Dari hasil penelitian diatas diketahui bahwa karakteristik responden penelitian ini berdasarkan umur mayoritas berumur 20-25 tahun yaitu sebanyak 7 responden (63,6\%). Berdasarkan pendidikan mayoritas adalah SMA atau Sederajat yaitu sebanyak 8 responden $(72,7 \%)$. Berdasarkan Pekerjaan mayoritas sebagai IRT yaitu sebanyak 6 responden (54,6\%). Sedangkan berdasarkan Parietas mayoritas responden Primipara yaitu sebanyak 7 responden $(63,6 \%)$.

Tabel 2. Rata-Rata Produksi ASI (Air Susu Ibu) Sebelum Diberikan Kacang Hijau.

\begin{tabular}{lll}
\hline No & Keterangan & Mean \\
\hline 1. & $\begin{array}{l}\text { Produksi ASI } \\
\text { sebelum } \\
\text { diberikan sari } \\
\text { kacang hijau }\end{array}$ & 0,045 \\
\hline
\end{tabular}

Dari tabel diatas dapat dilihat bahwa rata rata sebelum diberikan sari kacang hijau Produksi ASI adalah 0,045. Nilai ini didapatkan dari hasil perhitungan statisik 11 orang responden yang diobservasi produksi ASI-nya menggunakan 6 indikator penilaian produksi ASI. Diketahui produksi ASI dikatakan tidak lancar jika hasil penilaian produksi ASI $<4(\leq 0,5)$

Tabel 3. Rata-Rata Produksi ASI (Air Susu Ibu) Sesudah Diberikan Kacang Hijau

\begin{tabular}{llc}
\hline No & \multicolumn{1}{c}{ Keterangan } & Mean \\
\hline 1 & $\begin{array}{l}\text { Produksi ASI setelah } \\
\text { diberikan sari } \\
\text { kacang hijau }\end{array}$ & 0,82 \\
\hline
\end{tabular}

Dari tabel diatas dapat dilihat bahwa rata-rata sesudah diberikan sari kacang hijau Produksi ASI adalah 0,82. Hasil observasi setelah intervensi di dapatkan bahwa rata-rata produksi ASI responden $\geq 4(\geq 0,67)$

Tabel 4. Pengaruh Konsumsi Sari Kacang Hijau terhadap Produksi ASI pada ibu Menyusui di Klinik Pratama Tutun Sehati Tahun 2019

\begin{tabular}{llll}
\hline No & Pengaruh & Mean & $\begin{array}{c}\text { p- } \\
\text { value }\end{array}$ \\
\hline 1 & Kelancaran & & \\
& Produksi ASI & & \\
& Sebelum & 0,045 & \\
& Pemberian & & \\
& sari kacang & & \\
& hijau & & 0,046 \\
$2 \quad$ & Kelancaran & 0,82 & \\
& Produksi ASI & & \\
& Sesudah \\
& Pemberian \\
& sari kacang \\
& & & \\
& hijau & & \\
\hline
\end{tabular}

Berdasarkan hasil Penelitian diketahui bahwa rata-rata Produksi ASI sebelum diberikan Sari Kacang Hijau adalah 0,045 yang berarti tidak lancar dan rata-rata Produksi ASI sesudah diberikan Sari Kacang Hijau adalah 0,82 yang berarti lancar. Dan nilai $p$-value adalah 0,046 $(p \leq 0,05)$. Ini berarti ada pengaruh pemberian sari kacang hijau terhadap produksi ASI pada ibu menyusui di Klinik Pratama Tutun Sehati Desa Limau Manis Deli Serdang tahun 2019.

\section{PEMBAHASAN}

Penelitian ini sejalan dengan hasil penelitian Catur Erty Suksesty (2017) bahwa kenaikan berat badan bayi di hari ke 15 meningkat lebih tinggi pada kelompok yang mengkonsumsi jus kacang hijau dan daun adas dibandingkan yang tidak mengkonsumsi. Peningkatan Berat Badan bayi diduga karena kandungan polifenol dan flavonoid yang terdapat pada kacang hijau dan daun adas dapat meningkatkan 
produksi ASI sehingga merangsang pertumbuhan badan bayi.

Hal ini sejalan dengan teori Shohib (2006) yang menyebutkan bahwa kandungan dari kacang-kacangan mampu membantu proses pertumbuhan janin pada ibu hamil serta mengoptimalkan pengeluaran ASI serta kepekatan warna ASI pada ibu menyusui. Protein merupakan kandungan utama setelah karbohidrat di dalam kacang hijau yaitu sekitar 20-25 $\%$ protein ada pada kacang hijau mentah dengan daya cerna sekitar $77 \%$. Daya cerna kacang hijau dipengaruhi zat antigizi yaitu antirypsin dan tanin (polifenol). (Made A, 2009)

Polifenol dapat mempengaruhi produksi ASI. Selain polifenol, produksi ASI juga dipengaruhi oleh hormone oksitosin dan hormone prolaktin (Lany, 2010). Peningkatan oksitosin dan prolaktin di pengaruhi oleh protein dan asam amino dengan cara merangsang alveoli yang bekerja aktif saat pembentukan ASI. Hormon oksitosin akan menambah produksi ASI (Widyastuti, 2014)

Kandungan sari kacang hijau yang di konsumsi Ibu menjadi makanan tambahan yang dapat memenuhi kebutuhan gizi ibu menyusui sehingga kualitas dan volume ASI bertambah sehingga mendukung pertumbuhan dan perkembangan bayi. ASI merupakan sumber lemak dan protein yang penting bagi pertumbuhan dan nutrisi bayi. Kuantitas ASI yang dikonsumsi oleh bayi dan kandungan gizi dalam ASI sering digunakan untuk menilai kecukupan gizi selama proses menyusui. Salah satu upaya agar ibu berhasil dalam memberikan ASI secara ekslusif yaitu, ibu yang sedang menyusui bayinya harus mendapat tambahan makanan untuk menghindari produksi ASI menurun. Jika kandungan didalam makanan ibu menyusui tidak memenuhi kecukupan gizi, kelenjar-kelenjar pembuat air susu tidak akan bekerja dengan sempurna sehingga mempengaruhi produksi ASI.

\section{KESIMPULAN}

Sari kacang hijau dapat dijadikan sebagai alternatif untuk meningkatkan produksi ASI pada ibu menyusui. Ibu menyusui akan merasakan peningkatan produksi ASI rata-rata setelah 6 hari mengkonsumsi sari kacang hijau.

\section{DAFTAR PUSTAKA}

Ambarwati, 2018. Asuhan Kebidanan Nifas. Yogyakarta: Nuha Medika.

Aning, Ika Prasetya dan Yohanes Kristianto. 2014. 234+ Resep MPASI untuk Tumbuh Kembang Otak Anak.Sidoarjo: Genta Group Production Palm Square City TF-23.

Maryunani, A. 2018. Ilmu Kesehatan Anak Dalam Kebidanan. Jakarta : Trans Info Media

Maryunani, A. 2018. Inisiasi Menyusu Dini, ASI Ekslusif,dan Manajemen Laktasi. Jakarta: TIM.

Notoatmodjo, Soekidjo. 2017. Metodologi Penelitian Kesehatan. Jakarta: Rineka Cipta

Proverawati, Atikah dan Astuah Siti. 2018. Buku Ajar Gizi untuk Kebidanan. Yogyakarta: Numed

Pusdatin. 2017. Pusat Data dan Informasi Kementrian Kesehatan 2016. www.pusdatin.kemkes.go.id diakses pada tanggal 15 Maret 2019

Pusdatin. 2018. Pusat Data dan Informasi Kementrian

Kesehatan 2017. www.pusdatin.kemkes.go.id diakses pada tanggal 15 Maret 2019

Saleha, Siti. 2018. Asuhan Kebidanan pada Masa Nifas. Jakarta: Salemba Medika.

Suksesty, Catur Erty dan Marthia Ikhlasiah. 2017. Pengaruh Jus 
Received: 26 September 2019 :: Accepted: 15 Oktober 2019:: Published: 31 Oktober 2019

Campur Kacang Hijau

Terhadap Peningkatan Hormon

Prolaktin dan Berat Badan

Bayi,. Universitas

Muhammadiyah Tanggerang.

Jurnal Ilmiah bidan

Vol.11.no.3.2017. Diakses

pada tanggal 15 Maret 2019

Sulistyoningsih, H. 2017. Gizi untuk Kesehatan Ibu dan Anak. Yogyakarta: Graha Ilmu.

Sutanto, A. 2018. Asuhan Kebidanan Nifas dan Menyusui Teori dalam Praktik Kebidanan Profesional. Yogyakarta: Pustaka Baru Press.

Widaryanti, Rahayu. 2019. Pemberian Makan Bayi dan Anak. Yogyakarta: Budi Utama

Widayanti, Elok. 2015. Tanaman untuk Pelancar ASI di Sekitar Kita. Jawa Tengah: Kementrian Kesehatan Badan Penelitian dan Pengembangan Kesehatan Badan Penelitian dan Pengembangan Tanaman Obat dan Obat Tradisional.
Widyastuty, Kiky. 2014. Pengaruh Konsumsi Sari Kacang Hijau Terhadap Produksi Air Susu Ibu (ASI) pada Ibu Menyusui di Wilayah Kerja Puskesmas Dinoyo Malang. http://eprints.umm.ac.id/id/e print/25931 diakses pada tanggal 5 Maret 2019.

Winarsih. 2018. Pengantar Ilmu Gizi dalam Kebidanan. Yogyakarta: Pustaka Baru Pess.

Wulandari, Dewi Triloka dan Siti Roudhotul Jannah. 2015. Pengaruh Pemberian Sari Kacang Hijau pada Ibu Nifas dengan Kelancaran Produksi ASI di BPM Yuni Widaryanti, Amd.Keb Sumber Mulyo Jogoroto Jombang; Universitas Pesantren Tinngi Draul'Ulum Jombang. Jurnal EDU Health, Vol.5 no.2, September 2015. Diakses pada tanggal 15 Maret 2019 